\title{
EDITORIAL
}

\section{Endorsement of reporting guidelines is our next step}

\section{O endosso das diretrizes de publicação é o nosso próximo passo}

\author{
Rodrigo Pessoa Cavalcanti Lira ${ }^{1}$
}

\section{REFERENCES}

1. Wagoner K. Ao mestre com carinho, 365 reflexões sobre a arte de ensinar. São Paulo: Publifolha; 2002

2. The EQUATOR Network. Enhancing the QUAlity and Transparency Of Health Research [Internet]. Oxford; Centre for Statistics in Medicina [cited 2014 Feb 20] Available from:: http://www.equator-network.org/

3. Shamseer L, Galipeau J, Turner L, Moher D. Improving the reporting and usability of research studies. Can J Anaesth. 2013;60(4):337-44.

4. Moher D. Reporting research results: a moral obligation for all researchers. Can J Anaesth. 2007:54(5):331-5.
5. Groves T. Enhancing the quality and transparency of health research. BMJ. 2008; 337:a718.

6. Altman DG, Schulz KF, Moher D, Egger M, Davidoff F, Elbourne D, et al. The revised CONSORT statement for reporting randomized trials: explanation and elaboration. Ann Intern Med. 2001;134(8):663-94. Comment in: Aust Occup Ther J. 2009;56(1):72-3; Med Clin (Barc). 2005; 124(11):439; Ann Intern Med. 2002;136(12):926-7; author reply 926-7.

7. Hopewell S, Dutton S, Yu LM, Chan AW, Altman DG. The quality of reports of randomised trials in 2000 and 2006: comparative study of articles indexed in PubMed. BMJ. 2010;340:c723. Comment in: BMJ. 2010;340:c1432. 